\title{
Belphégor
}

Littérature populaire et culture médiatique

15-1 | 2017

1936: les Jeux olympiques dans la presse

internationale

\section{Adrien Genoudet, Dessiner l'histoire. Pour une histoire visuelle}

Philippe PAOLUCCI

\section{(2) OpenEdition \\ Journals}

Electronic version

URL: http://journals.openedition.org/belphegor/862

DOI: $10.4000 /$ belphegor.862

ISSN: 1499-7185

Publisher

LPCM

Electronic reference

Philippe PAOLUCCI, «Adrien Genoudet, Dessiner I'histoire. Pour une histoire visuelle », Belphégor [Online], 15-1 | 2017, Online since 18 April 2017, connection on 24 September 2020. URL : http://

journals.openedition.org/belphegor/862 ; DOI : https://doi.org/10.4000/belphegor.862

This text was automatically generated on 24 September 2020.

\section{(c) (i)}

Belphégor est mis à disposition selon les termes de la Licence Creative Commons Attribution - Pas d'Utilisation Commerciale - Pas de Modification 4.0 International. 



